\begin{tabular}{|c|c|}
\hline & $\begin{array}{l}\text { International Journal of Trend in Scientific } \\
\text { Research and Development (IJTSRD) }\end{array}$ \\
\hline 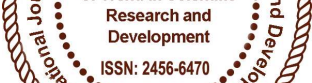 & International Open Access Journal \\
\hline 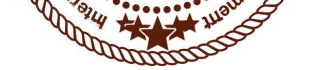 & ISSN No: 2456 - 6470 | www.ijtsrd.com | Volume - 2 | Issue - 2 \\
\hline
\end{tabular}

\title{
Camouflage of Fragmentation and Alienation in Nathanael West's A Cool Million
}

\author{
P. Ranjithkumar \\ Ph.D Research Scholar, Department of English \\ Annamalai University, Chidambaram, Tamil Nadu
}

\author{
Dr. R. Palanivel \\ Assistant Professor, English Wing DDE, \\ Annamalai University, Chidambaram, Tamil Nadu
}

\section{ABSTRACT}

This paper examines West's satire and parody of the various schools of philosophic and artistic concepts that precede and underpin the Modem movement. By revealing the absurdity of Western thought in the early twentieth century, West was able to show the fragmentation and alienate he perceived in both society and the self. The revelation of this detritus becomes a deconstructive device that simultaneously demonstrates ways of creating meaning in the twentieth century, and that condemns any philosophy based on escape from suffering.

The novel A Cool Million, variously attack artistic or political formulae that privilege escape from culture's degradation, or that offer erroneous promises of subjective or cultural wholeness. West's life and art, then, exhibits the usefulness of the camouflage in the grim battle for the formation of artistic and political subjectivity.

Nathanael West's novel stands as significant reminders of the worry that plagued America and the reality almost a century back. There may be undoubtedly a greater amount that can, and should, a chance to be said around West as much worth of effort. Routes for considering regarding culture, politics, history, art, and the puzzling state of constantly human need aid all miserably joined Previously, as much dream. Such worries talk potently and straightforwardly to those birthplaces of the exhibit.
Fragmentation and alienation are themes that carry over into West's novel, A Cool Million. West's novel, A Cool Million, would attack, exposing the grinding greed underlying the capitalist cliches of the American Dream. Because of this satire, the novel is important not only in what it exposes but also because it marks the turn in West's work to a much more specifically American literature.

Fragmentation and alienation are of the modern world having deeply affected not only the realms of politics and rhetoric, but also the everyday landscape of common objects. There would be nothing but the blank suffering of alienated and fragmented beings in a shattered world.

\section{Camouflage of Fragmentation and Alienation in Nathanael West's $A$ Cool Million}

Nathanael West might have been conceived Nathan Weinstein clinched alongside New York Cityon October 17, 1903. (He legitimately transformed as much name for 1926.) West was the child for Jewish foreigners max Weinstein, A prosperous building contractor, Anna Wallenstein Weinstein. Mr. Weinstein needed his son to try under those family business also offered Nathan duplicates about the Horatio Alger books, an arrangement about books done which. straightforward junior men do well to themselves in business. He laid as much path under Tufts University, which expelled him for poor grades; 
et cetera got himself admitted on tan college by using somebody else's transcripts. West moved on starting with tan to 1924, where he might have been better referred to as much sense for cleverness enthusiasm imparities over any academic abilities.

Then afterward completing college West went through two a considerable length of time over Paris. He was called back of the united states On 1927, as those family's contracting business might have been encountering those initial investment shudders that would become that's only the tip of the iceberg broad over 1929. West's family members discovered him an arrangement of jobs overseeing private hotels in this way that he might gain a living. Through these jobs, West might have been ready to provide a number impoverished writers with without rent rentdiscount spots should sit tight previously, New York city and on meet many journalists who might before long get famous, including Dashiell Hammett, Erskine Caldwell Lillian Hellman and encountered with urban decay because of deindustrialization, engineering imagined, government lodgin. J. Perelman, West's brother by marriage. West found those frantic exists from claiming exactly for his tenants fascinating, he might have been referred to steam open Furthermore perused their letters. He disregarded the realist fiction for as much American contemporaries in favor for French surrealists furthermore British also Irish poets of the 1890s, in particular Oscar Wilde. West's diversions centered on surprising artistic style and in addition surprising substance. He turned into intrigued by Christianity and mysticism, concerning illustration encountered alternately communicated through writing Also craft. Throughout this period, he done as much to begin with book, The dream of Balso Snell, and distributed it will very nearly no basic alternately businesses perceive in 1931.

The Depression started early in West's family, with his father's business. Beginning to lag in 1928 and financial troubles that brought West home from Paris early. Martin argues that "the personal disaster of West's hopes preceded the national crash - giving him a feeling of individual bitterness - and also that the national experience of disaster followed soon after his own, imparting, to some extent, a sense of the community of disaster" (106). This financial disaster did not sit well with West, whose parents had inundated him and his sisters with the language and literature of success throughout their lives. It was this rhetoric that West's third novel, A Cool Million, would attack, exposing the grinding greed underlying the capitalist cliches of the American Dream. Because of this satire, the novel is important not only in what it exposes but also because it marks the turn in West's work to a much more specifically American literature.

West demonstrated the camouflage's destructive force and constructive potential in both his writing and his personal life. The novel $A$ Cool Million, variously attack artistic or political formulae that privilege escape from culture's degradation, or that offer erroneous promises of subjective or cultural wholeness. West's life and art, then, exhibit the usefulness of the mask in the grim battle for the formation of artistic and political subjectivity.

Fragmentation and alienation are themes that carry over into West's novel, A Cool Million. The protagonist and erstwhile hero of this novel, Lemuel Pitkin, appear in the narrative as the only character not wearing a mask. This inability to construct camouflage for himself leaves him unequipped to recognize and see through the masks that others wear, and that others will construct and place upon him. Pitkin is an innocent; he sincerely believes the clichés of virtue that make up the stereotypical American spirit. Because Pitkin has no camouflage of his own with which to resist other, competing camouflage, the other characters can force him to wear masks without his awareness of them or their meaning. Steiner, points out that West's American myth is an "inverse corollary to the 'constructive' egoism of the Alger myth" (159). This paper replace "constructive" with "constructionist." Alger is a self-made man; Pitkin is a man unmade by others.

Pitkin's dismantling occurs through a series of grievous physical injuries. Like the house in which he grew up, Pitkin is taken apart, piece by piece, and scattered. He is reconstructed out of context, a fragmented being made of a mask not of his devising. Lem seems to be one of the few characters in West who has some sort of core being; perhaps not an essence, but an internalized set of values which are not negotiable. Ironically, the static nature of his qualities provides the vaudevillian comedy to his misadventures. Pitkin is singularly unaffected by the somatic rearrangements that are made to his physical presence. The violence done to him is somehow not real; it is all somehow a comedy.

This point is driven home when Pitkin actually gets a 
job working in a vaudeville act with two comedians. The act consists of them exchanging a "breezy crossfire of smart cracks," then they "turned on Lem and beat him violently over the head and body with their rolled-up newspapers. Their object was to knock off his toupee or to knock out his teeth and eye" (West 232-33). To top it all off, "For a final curtain call they brought out an enormous wooden mallet labeled 'The Works' and with it completely demolished our hero. His toupee flew off, his eye and teeth popped out, and his wooden leg was knocked into the audience" (233). Despite his physical demolition, Pitkin's prostheses can be easily reattached; Pitkin's ability to repeat this process creates a link between him and the house in which he was raised.

Pitkin's values are a product of his upbringing; the house in which he grows up is a haven of filial attachment where he attends closely upon his mother. This house is a symbol of these values, and it falls prey to capitalistic greed. This powerful symbol of small-town values and family unity is destroyed when Asa Goldstein buys the house from the bank, despite the fact that there are still people living in it, and dismantles it in order to put it back together in his shop window in New York (132). Like Pitkin, it is taken apart, bought and sold by agencies mysterious and powerful and put back together again out of context. The wholesome "American" values symbolized by the house and still subscribed to by Pitkin himself are as well placed out of context: in modern-day America, these values no longer make sense. They provide no defense against dissolution or dismemberment. This process of decontextualization fits Pitkin and the house with masks, constructed for them by others. Pitkin's camouflage as the representative of a new American fascist organization leads him to be textually constructed as a martyr: his identity is posthumously reconstructed according to the National Revolutionary Party's designs, designs opaque to Pitkin himself. The ultimate fate of the house is never made clear, however.

If Pitkin's house stands as a building that parallels his demolition and fragmentation, Wu Fong's brothel stands as a sort of foil or evil twin, and its masking involves not Pitkin but Betty Prail. Wu Fong has cleverly constructed each room of his whorehouse to reflect a style specific to various geographic locations (156, 188-90). The careful construction of these decontextualized environments and costumes for the prostitutes constitutes a practice of masking that makes the sexual violence of prostitution not quite real. Perhaps the way to explain the apparent immunity of Lemuel and Betty to the violence wreaked upon them is the idea that "the mass...is anaesthetized to real experience. In popular apprehension, rape, for example, is not the brutal and painful forcing of a real woman, but something histrionic, played out in an 'ideal' world of fancy, somehow detached from rapist and rapee - therefore, potentially ludicrous" (Steiner 168). This insulation from violence exhibits itself, of course, in Lem's resiliency, but Betty Prail is also apparently immune to violence; she is raped too many times to count, but suffers no ill-effects, and her personality or values do not change in the slightest way.

Both Betty and Pitkin are unwittingly guided on this journey of dissolution by the founder of the National Revolutionary Party, Nathan "Shagpoke" Whipple. Whipple is the most powerful and insidious performer of roles and enactor of camouflage in the novel and his unflagging rhetoric cast him as a leader and a true patriot as well as a kindly avuncular figure for Pitkin. Whipple uses his political rhetoric to constitute himself as maniacally optimistic, and this camouflage, in awe of the American Dream, guides Pitkin through various misadventures until the unsuspecting hero is literally worn away, piece by piece, and finally killed.

Whipple uses his rhetoric to demarcate a role for Pitkin, creating an identity for the unwitting bumpkin as more than a simple country boy: Pitkin becomes a poster boy for Whipple's Fascist movement and finally a martyr for a cause he never understands. Despite Pitkin's best efforts to keep up with his own ethics and ideals, his identity is redefined for him by Whipple, who uses the patriotic rhetoric of the American Dream to create a camouflage, a new persona, for Pitkin. And Pitkin, as discussed above, has no existing camouflage: he is easy prey, because he is unequipped to understand what is happening to him.

Whipple begins shaping Pitkin's actions with inspiring political rhetoric that correlates patriotism with capitalism (137) and excoriates Whipple's improbable enemies: "I blame Wall Street and the Jewish international bankers....It was Wall Street working hand in hand with the Communists that caused my downfall....there are two evils undermining this country....Wall Street and the communists" (159). 
Later, Whipple begins laying plans for the National Revolutionary Party when he gives a political speech in the street: "We must drive the Jewish international bankers out of Wall Street! We must destroy the Bolshevik labor unions! We must purge our country of all the alien elements and ideas that now infest her!" (174). Logically, these claims make no sense: Whipple spouts invective against capitalists and socialists. Ironically, the narrative world proves Whipple correct in his claims that the Jewish international bankers and the Communists are working together; as he is signing up recruits for his Revolutionary Party, their operatives appear and violently disperse the crowd (175-76). Whipple's camouflage, his rhetoric and claims of conspiracy, seem almost to conjure the conspiracy from the air like a self-fulfilling prophecy.

Eventually, Whipple's "Leather Shirts" take over the country, declaring a dictatorship and establishing Whipple's National Revolutionary Party as the dominant political machine. Pitkin is invited to make a speech at a rally and is assassinated before he can say a full sentence by a joint operative of the Jewish international bankers and the Communists. Pitkin's Birthday becomes a national holiday, and a song is sung that casts him as a loyal follower of Whipple who bravely defied death to serve the revolution (23738). Whipple, in the final act of masking in the novel, takes the shattered and destroyed memory of what Pitkin was and rearranges that story into a tale of bravery and martyrdom for a sacred political cause: "Through his martyrdom the National Revolutionary Party triumphed, and by that triumph this country was delivered from sophistication, Marxism and International Capitalism. Through the National Revolution its people were purged of alien diseases and America became again American" (238). Clearly Pitkin had no intention of playing any part whatsoever in this revolution; there is no evidence that politics ever entered his mind: all he was able to see was the suffering caused by unemployment during the Depression, in which the novel's action is set. With his dismantling reconstructed as martyrdom, Lemuel Pitkin is the perfect example of a subject completely without capacities to mask: in the world that Mr. West has constructed for us, such a being cannot survive. Pitkin becomes a blank face onto which others can fit whatever camouflage they like.

The disturbing quality of Pitkin's demolition is that he has been characterized as a collection of prosthetic body parts. Seeing Pitkin as a conglomeration of objects recalls once again the theme of detritus that runs throughout West's work. Later in the story, Whipple and Pitkin encounter the Chamber of American Horrors, which Whipple sees as distributing propaganda. By putting on a play showing greedy bond salesmen heartlessly watching widows and children starve to death, Sylvanus Snodgrasse, proprietor of the Chamber, is proposing that capitalism is a misguided system; of course, Whipple will have none of this, as "The distinction must be made between bad capitalists and good capitalists, between the parasites and the creators" for Whipple is "against the parasitical international bankers, but not the creative American capitalists, like Henry Ford" (226). Although this somewhat qualifies his polemic against both capitalists and communists, Whipple's distinction is a stretch. But the inherent logic of his position has no bearing on his followers: his status as an ex-President of the United States and his constitution of himself as a "real" American are convincing enough to his listeners.

Fragmentation and alienation are of the modern world having deeply affected not only the realms of politics and rhetoric, but also the everyday landscape of common objects. The Chamber of American Horrors exhibits "collections of objects whose distinction lay in the great skill with which their materials had been disguised. Paper had been made to look like wood, wood like rubber, rubber like steel, steel like cheese, cheese like glass, and, finally, glass like paper" (223). Everything is under suspicion; nothing can be trusted. Like Pitkin, who is presented as a subject with an untouchable core or essence, the essences of the materials in the Chamber of Horrors are perverted, made to perform roles for which they are not meant. This is the really disturbing quality of Pitkin's situation: he has been camouflaged, demolished and reconstituted for unnatural use. The danger and perversion of such an enterprise provides an easy segue into West's novel, which describes not only a chamber of American horrors, but an entire city. There would be nothing but the blank suffering of alienated and fragmented beings in a shattered world.

\section{Works Cited}

1) West, Nathanael, A Cool Million. New York: Covici-Friede, 1934-Print. 
International Journal of Trend in Scientific Research and Development (IJTSRD) ISSN: 2456-6470

2) Baker, Houston A., Jr. Modernism and the Harlem Renaissance. Chicago: U of Chicago P, 1987.Print.

3) Steiner, T. R. "West's Lemuel and the American Dream." Southern Review 4.7(1971) RPt. In
Modern Critical Views: Nathanael West. Ed. Harald, New York: Chrlsea,1986.99-109.Print.

4) West, Nathanael. Nathanael West: Novels and Other Writings. Ed. Sacvan Bercovitch. New York: The Library of America, 1997.Print.

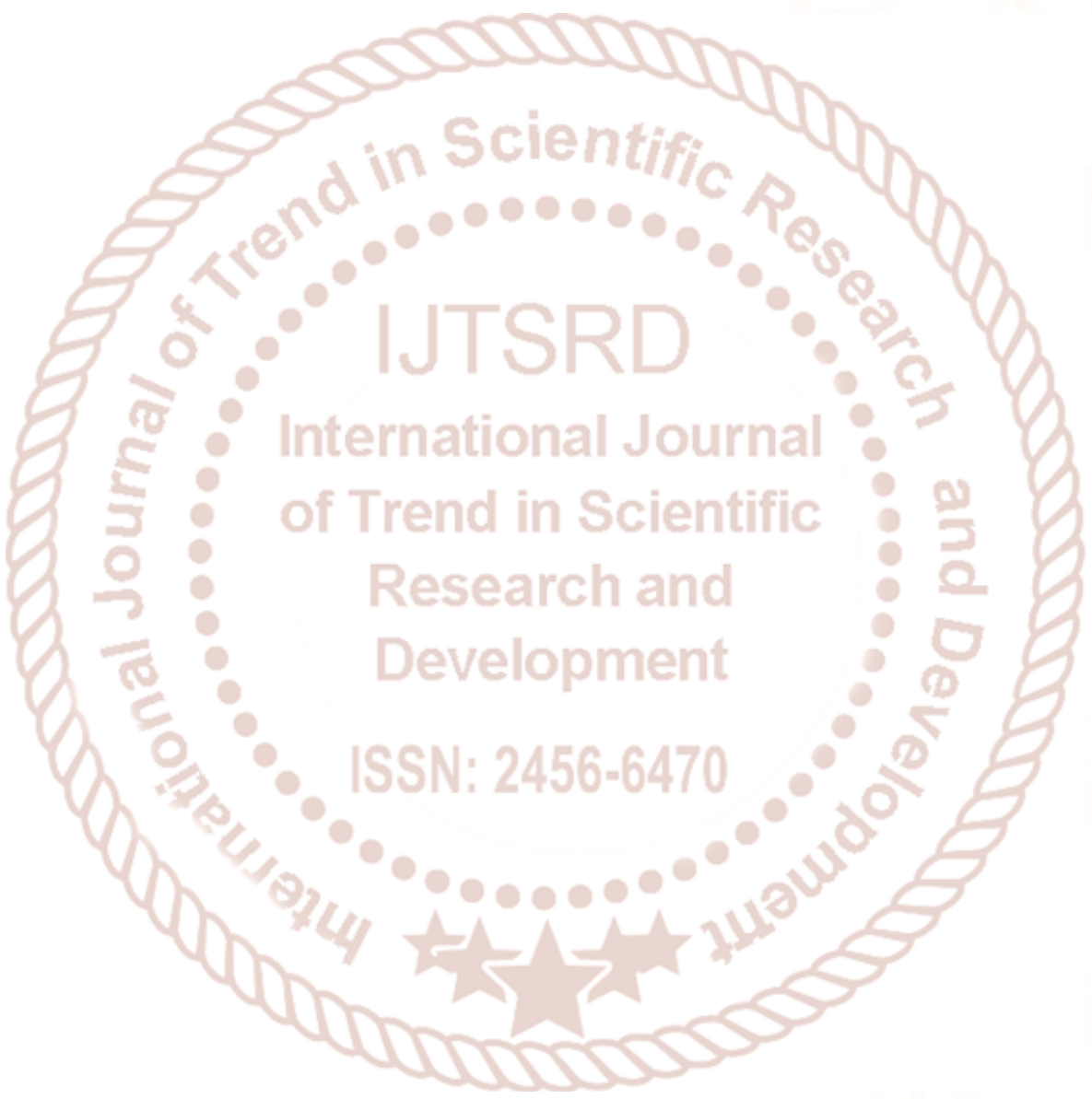

